\title{
ESTIMATES OF TECHNO-ECONOMIC LOSS FROM CONVERTING SAWNWOOD TO FURNITURE PARTS IN A DESIGNATED WOOD PROCESSING OUTFIT
}

\author{
Solomon Lagbenga Larinde ${ }^{1}$, Andrew Agbontalor Erakhrumen ${ }^{2 *}$ \\ ${ }^{1}$ Department of Forestry and Wildlife Management, Faculty of Agriculture, University of Port Harcourt, Port Harcourt, Nigeria \\ ${ }^{2 *}$ Department of Forest Resources and Wildlife Management, Faculty of Agriculture, University of Benin, Benin City, Nigeria - \\ andrew.erakhrumen@uniben.edu \\ Received for publication: 08/06/2019 - Accepted for publication: 13/02/2020
}

\begin{abstract}
Resumo
Estimativas de perda techno-econômica da conversão de madeira serrada em peças de móveis em um equipamento de processamento de madeira designada. Este estudo foi realizado, para contribuir com isso, usando madeira serrada seca ao ar de três madeiras duras tropicais (Afzelia africana, Milicia excelsa e Tectona grandis) com dimensão média $117 \times 305 \times 1830 \mathrm{~mm}$ para produzir peças de móveis de dimensões $25(+3) \mathrm{mm} \times$ $600(+20) \mathrm{mm} / 900(+20) \mathrm{mm} / 120(+20) \mathrm{mm} / 150(+20) \mathrm{mm} / 180(+20) \mathrm{mm} / 2100(+20) \mathrm{mm} \mathrm{com} \mathrm{os}$ resíduos de madeira gerados categorizados e quantificados. Os dados foram analisados por meio de estatística descritiva, análise de variância, diferença menos significativa para separação de médias e análise de regressão com resíduos técnicos e econômicos como variáveis dependentes para as três espécies. O volume total médio de entrada variou de 23,11 $\pm 2,98 \mathrm{~m} 3$ a 24,63 $\pm 0,55 \mathrm{~m} 3$ para $A$. africana e $T$. grandis, respectivamente, enquanto o volume de produção bruto e líquido variou de $12,01 \pm 1,78 \mathrm{~m}^{3}$ a $16,44 \pm 0,38 \mathrm{~m}^{3}$ e 9,52 $\pm 1,42 \mathrm{~m}^{3}$ a 14,44 . \pm $0,38 \mathrm{~m}^{3}$ para $A$. africana e $T$. grandis, respectivamente. Os resíduos econômicos variaram de $2,00 \pm 0,10 \mathrm{~m}^{3}$ a $2,49 \pm 0,40 \mathrm{~m}^{3}$ e os resíduos econômicos como porcentagem do volume bruto de produção variaram de $12,23 \pm$ $0,64 \mathrm{~m}^{3}$ a $20,73 \pm 2,59 \mathrm{~m}^{3}$ para $T$. grandis e A. africana, respectivamente, enquanto a faixa foi de $10,19 \pm 0,25$ $\mathrm{m}^{3}$ a $13,59 \pm 1,83 \mathrm{~m}^{3}$ para $T$. grandis e A. africana, respectivamente, para o volume total de resíduos. Além disso, o percentual médio do volume recuperado bruto e líquido variou de 50,27 $\pm 2,42 \%$ a $67,22 \pm 0,34 \%$ e $41,21 \pm 2,32 \%$ a $58,58 \pm 0,62 \%$ para $A$. africana e $T$. grandis, respectivamente. O volume percentual total de resíduos foi menor para $T$. grandis $(41,42 \pm 0,62 \%)$ e maior para A. africana $(58,79 \pm 2,32 \%)$.

Palavras-chave: Madeira tropical, conversão secundária de madeira, resíduos, comércio internacional
\end{abstract}

\begin{abstract}
Quantification and reduction of residues generated through wood conversion are important in wood resources management. This study was carried out, to contribute to this, by using air-dried sawnwood from three tropical hardwood (Afzelia africana, Milicia excelsa and Tectona grandis) with mean dimension $117 \times 305 \times 1830 \mathrm{~mm}$ to produce furniture parts of dimensions $25(+3) \mathrm{mm} \times 600(+20) \mathrm{mm} / 900(+20) \mathrm{mm} / 120(+20) \mathrm{mm} / 150(+20)$ $\mathrm{mm} / 180(+20) \mathrm{mm} / 2100(+20) \mathrm{mm}$ with the generated wood residues categorised and quantified. Data were analysed using descriptive statistics, analysis of variance, least significant difference for separating means and regression analysis having technical and economical residues as dependent variables for the three species. Mean total input volume ranged from $23.11 \pm 2.98 \mathrm{~m}^{3}$ to $24.63 \pm 0.55 \mathrm{~m}^{3}$ for $A$. africana and $T$. grandis respectively while that for gross and net output volume ranged from $12.01 \pm 1.78 \mathrm{~m}^{3}$ to $16.44 \pm 0.38 \mathrm{~m}^{3}$ and $9.52 \pm 1.42 \mathrm{~m}^{3}$ to $14.44 \pm 0.38 \mathrm{~m}^{3}$ for $A$. africana and $T$. grandis respectively. Economical residues ranged from $2.00 \pm 0.10 \mathrm{~m}^{3}$ to $2.49 \pm 0.40 \mathrm{~m}^{3}$ and economical residues as percentage of gross output volume ranged from $12.23 \pm 0.64 \mathrm{~m}^{3}$ to $20.73 \pm 2.59 \mathrm{~m}^{3}$ for $T$. grandis and A. africana respectively while the range was from $10.19 \pm 0.25 \mathrm{~m}^{3}$ to $13.59 \pm 1.83 \mathrm{~m}^{3}$ for $T$. grandis and A. africana respectively for total volume of residues. Additionally, mean percentage gross and net recovered volume ranged from $50.27 \pm 2.42 \%$ to $67.22 \pm 0.34 \%$ and $41.21 \pm 2.32 \%$ to $58.58 \pm 0.62 \%$ for $A$. africana and $T$. grandis respectively. Total percentage volume of residues was least for $T$. grandis $(41.42 \pm 0.62 \%)$ and highest for A. africana $(58.79 \pm 2.32 \%)$. Based on these outcomes, it was recommended that increased effort is needed to improve capacities and facilities for lesser generation of residues during mechanical wood processing.
\end{abstract}

Keywords: Tropical hardwood, secondary wood conversion, residues, international trade

\section{INTRODUCTION}

The currently increasing challenge being posed to sustainable supply of hardwood, in terms of inadequacy in quantity and quality, owing to their decline in natural forests - ecosystems that are themselves diminishing in size - has led to rising interests in seeking for means of surmounting this challenge particularly in developing countries within the tropical region. Among the suggestions for achieving this aim, apart from planting new and re-planting of harvested and/or degraded forests, is to adopt strategies that will assist the different stakeholders in more sustainable utilisation of forest and its resources in general, and for wood, in ways that will enhance more

FLORESTA, Curitiba, PR, v. 51, n. 1, p. 080-089, jan/mar 2021.

Larinde, S. L. et.al.

ISSN eletrônico 1982-4688

DOI: 10.5380/rf.v51 i1. 67331 
sustainability and reduce negative impacts. It is well known that generating different types of wood residues are significant means by which loss of voluminous lignocellulosic biomass material occur in wood processing industry. Poor processing practices result in large volume of wood residues, low volume of recovered lumber and increased cost of production. Thus, efforts that will reduce wood loss during processing activities would benefit timber industry and trade.

In the past and up to very recently, residues such as bark, sawdust, wood chips, scraps of wood, rejects, slabs, edgings and trimmings, veneer log cores, veneer rejects, among other residues, from sawmilling, carpentry and joinery production outfits, were considered as waste and mostly discarded for incineration and sometimes utilised as biomass fuel for cooking and heating. However, some current realities, earlier described, are encouraging changes in management strategies for these residues, as also reported as outcome of another study by Larinde et al. (2018). It is important to note that wood residues have been defined in different ways. For instance, FAO (2000) defined wood residues as the volume of round wood that is left over after the production of forest products in the forest processing industry (i.e. forest processing residues) and that has not been reduced to chips or particles. Chips and particles, in this context, are defined as wood that has been deliberately reduced to small pieces during the manufacture of other wood products.

As briefly pointed out above, the tropical forests are depleting at an unprecedented rate making the wood industries in most part of the tropics including those in other parts of the world that depend on wood import from these tropical forests to stand the risk of facing log supply shortage. In an IITO (2000) annual review assessment of the world timber situation, it was indicated that the timber industries in the tropics are facing raw material supply shortage at an unprecedented scale. It is, therefore, crucial that conversion processes relating to the use of wood as raw materials for product manufacturing should be continuously studied for necessary possible improvements, with particular attention to be focussed on residues generated from wood processing firms. This assertion should not be implied to mean that one is unmindful of earlier similar studies that focused on residues incurred within and out of logging sites including mechanical processing plants like sawmills, plywood mills and some pulp and paper mills.

These earlier studies, just being referred to, have been carried out and reported in many parts of the world, Nigeria included. Amongst these studies are those of Badejo and Giwa (1985), Noack (1995), Larinde et al. (2006), Akande et al. (2007), Larinde and Popoola (2008), Erakhrumen and Onymali (2016) and Erakhrumen and Idele (2016). Irrespective of the availability of these earlier published studies in the literature, there is still the need for certain information not covered within the scope of these earlier mentioned studies such as the one concerning the quantification of volume of residues generated specifically from sawnwood and secondary processed wood products that are converted and processed into furniture parts. It is for this reason that necessity exists for understanding the factors that affect the generation, volume and possible utilisation of wood residues from different stages in the manufacture of furniture parts and this is critical to maximising their known and yet to be known economic values.

Although some of the wood residues generated by primary and secondary wood products industries are being utilised in the production of pulp chips, composite production, fuel for energy production, among other purposes, nevertheless, a significant quantity of these residues still find their way into the waste stream, thereby rendering this renewable natural resource - in this instance being considered as waste - grossly underutilised. Of course, for entrepreneurs to take advantage of the market opportunities that exist for wood residues, information will be needed on the types being generated, quantity and their level of availability, production rates and other associated factors. Once wood residues have been characterised, manufacturers that are to utilise them can plan strategies that incorporate their utilisation and make necessary policy decisions. In line with this thinking, this study was therefore carried out to quantify the volume of solid wood residues generated in a processing facility for furniture parts and to specifically determine the types (both technical and economical residues) in the production process with focus on sawnwood from three tropical hardwood species namely Afzelia africana, Milicia excelsa and Tectona grandis.

\section{MATERIALS AND METHODS}

Data collection for this study was carried out in the wood workshop of the Industrial Development Unit of Forestry Research Institute of Nigeria, Ibadan, Nigeria. The logs from trees of A. africana and M. excelsa were obtained from natural forests within the southern part of the country while those of $T$. grandis were plantationgrown. Wood from A. africana (also known as African mahogany or Apa) is considered to be of very good quality suitable for use as a substitute for Swietenia spp. (mahogany). It is often exported to Europe but has declined in population numbers and by 1998 it was re-assessed and re-classified as 'Vulnerable' on the IUCN red list of species due to the threat of over-exploitation for timber on the international market with a demand as much as that of teak

FLORESTA, Curitiba, PR, v. 51, n. 1, p. 080-089, jan/mar 2021.

Larinde, S. L. et.al.

ISSN eletrônico 1982-4688

DOI: $10.5380 /$ rf.v51 i1. 67331 
for some uses such as keels, stems and panels, for bridges, as well as interior fittings (GÉRARD; LOUPPE 2011, FERN 2014).

Milicia excelsa (Iroko) is also a highly valued commercial timber in Africa, for which demand is large. It is used for construction work, ship building and marine carpentry, sleepers, sluice gates, framework, trucks, draining boards, outdoor and indoor joinery, stairs, doors, frames, garden furniture, cabinet work, panelling, flooring and profile boards for decorative and structural uses thereby making it very valuable for export as major timber in international trade. Milicia excelsa is classified as 'Near Threatened' in the IUCN Red List of Threatened Species (last assessed in January, 1998), the main threats being habitat loss and degradation due to expanding agriculture, over exploitation of the wood, and Phytolyma attacks (OFORI 2007). At present its exploitation is not sustainable in most countries - it requires protection and exploitation has to be limited if it is to become sustainable (FERN 2014).

Tectona grandis (Teak) is the preferred wood for naval construction, elements of boat hulls and bridges of boats because of its extreme resistance to decay and corrosive activity of water. It is suitable for a variety of uses: luxury cabinet-work, frames (doors and windows), furniture and joinery with solid wood, parquet flooring, staircases, carpentry, garden furniture, railway sleepers, bridges and other construction in contact with water or the ground, electricity and telephone poles, fence posts, railcars, barrels and vats for liquids, even corrosive ones, various utensils (except tool handles because the wood is brittle), turnery and sculpturing. Currently, the world production of wood from teak (about 2 million $\mathrm{m}^{3} / \mathrm{year}$ ) covers $1 \%$ of the world demand for timber, and it is the timber most in demand (LOUPPE 2005). Teak is agreed to be one of the most important timbers in the world with a rare combination of superior physical and mechanical properties making it a paragon of timber (FERN 2014).

According to published data, the wood of A. africana is medium-weight to moderately heavy, with a density of $720-850 \mathrm{~kg} / \mathrm{m}^{3}$ at $12 \%$ moisture content (GÉRARD; LOUPPE 2011). The shrinkage rates are low, from green to oven dry $2.5-3.5 \%$ radial and 3.5-5.0\% tangential. Once dry, the wood is very stable in service. The wood of $M$. excelsa has a density of $550-750 \mathrm{~kg} / \mathrm{m}^{3}$ at $12 \%$ moisture content with its shrinkage rates from green to oven dry being 1.7-4.1(-5.6)\% radial and 2.4-6.3(-9.8)\% tangential. Teak is a medium-weight wood. At $12 \%$ moisture content, the density is (480-)610-730(-850) $\mathrm{kg} / \mathrm{m}^{3}$. The rates of shrinkage are low, from green to $12 \%$ moisture content $0.7-1.5 \%$ radial and $1.1-2.5 \%$ tangential, and from green to oven dry $1.8-3.7 \%$ radial and $3.2-6.2 \%$ tangential (LOUPPE 2005, OFORI 2007, GÉRARD; LOUPPE 2011).

The logs obtained from the three species of tree (A. africana, M. excelsa and T. grandis) for this study were all converted to sawnwood having a mean dimension of 117 x $305 \times 1830 \mathrm{~mm}$ (on the radial $\mathrm{x}$ tangential $\mathrm{x}$ longitudinal planes respectively) with a CD6 horizontal band saw machine. In defining sawnwood, according to FAO (2016), it was stated that they are wood that has been produced from both domestic and imported roundwood, either by sawing lengthways or by a profile-chipping process and that exceeds $6 \mathrm{~mm}$ in thickness. It includes planks, beams, joists, boards, rafters, scantlings, laths, boxboards and "lumber", etc., in the following forms: non-planed, planed, end-jointed (for example finger-jointed), etc. It excludes sleepers, wooden flooring, mouldings (sawnwood continuously shaped along any of its edges or faces, like tongued, grooved, rebated, V-jointed, beaded, moulded, rounded or the like) and sawnwood produced by re-sawing previously sawn pieces.

The other mechanical equipment used in converting sawnwood from the logs to the different furniture parts in this wood workshop were the multiple rip-saw machine also referred to as multiple-edger machine and cross-cut sawing machine equipped with a back-gauge. Shown in Fig. 1 is the multiple rip-saw machine (MULTISAW OGAM PO 340) that was of multi blade (between 8 and 12 blades) with engine capacity of 50hp $(37 \mathrm{~kW})$ and automatic motorised feeder. Overall dimensions of this multiple rip-saw machine are: Length = $242 \mathrm{~cm}$; Width $=162 \mathrm{~cm}$; Height $=200 \mathrm{~cm}$; Weight $=3000 \mathrm{~kg}$. Feed speed was $4-36 \mathrm{~m} / \mathrm{min}$ while minimum and maximum blade diameter were $250 / 350 \mathrm{~mm}$. Maximum width was $340 \mathrm{~mm}$, shaft diameter was $70 \mathrm{~mm}$ while maximum cutting height was $130 \mathrm{~mm}$. In addition, the same Fig. 1 shows the WADKIN BRA radial arm crosscut saw designed with long-term accuracy and durability and is available in $350 \mathrm{~mm}, 400 \mathrm{~mm}$ and $450 \mathrm{~mm}$ models.

It is, indeed, noteworthy that all the equipment mentioned above are not the only available or known ones for wood conversion in Nigeria as some wood conversion outfits, although still limited in number, possess heavy industrial wood processing equipment. Irrespective of these few outfits, the country's current technological advancement is low and this impact on her industries including those of sawmilling (ERAKHRUMEN; IDELE 2016). The sawnwood, with mean dimension of 117 x 305 x 1830mm (on the radial x tangential x longitudinal planes respectively), from the three hardwood species earlier named as A. africana, M. excelsa and T. grandis were used to produce high-quality pieces of furniture parts that are FAS free of sap, with no knots, no worm, and straight grain, smooth, straight and even cut, properly square edged and cross-cut using the multiple rip-saw machine.

The furniture parts were produced for making wooden legs for table, sofa feet, chair/table legs and top, back for chairs, stool tops, seats, chair slats, wooden garden chairs, tables and benches, edge glued panels, cabinet doors, drawer fronts, face frames, mouldings, picture frames, etc. The dimensions of the pieces of furniture parts

FLORESTA, Curitiba, PR, v. 51, n. 1, p. 080-089, jan/mar 2021.

Larinde, S. L. et.al.

ISSN eletrônico 1982-4688

DOI: $10.5380 /$ rf.v51 i1. 67331 
were: $25(+3) \mathrm{mm} \times 600(+20) \mathrm{mm} / 900(+20) \mathrm{mm} / 120(+20) \mathrm{mm} / 150(+20) \mathrm{mm} / 180(+20) \mathrm{mm} / 2100(+20) \mathrm{mm}$. Among the other dimensions were: $28 \times 105 \times 620 \mathrm{~mm}, 28 \times 105 \times 720 \mathrm{~mm}, 28 \times 105 \times 820 \mathrm{~mm}, 28 \times 105 \times 920 \mathrm{~mm}$, $28 \times 105 \times 1020 \mathrm{~mm}, \quad 28 \times 84 \times 620 \mathrm{~mm}, 28 \times 84 \times 720 \mathrm{~mm}, 28 \times 84 \times 820 \mathrm{~mm}, 28 \times 84 \times 920 \mathrm{~mm}, 28 \times 84 \times 1020 \mathrm{~mm}$, $28 \times 65 \times 320 \mathrm{~mm}, 28 \times 65 \times 640 \mathrm{~mm}, 28 \times 65 \times 960 \mathrm{~mm}$. The processed furniture parts were stacked away from the work area of the workshop (Fig. 1) and those for export were packaged (Fig. 4) for onward loading into shipping containers. The wood moisture content was based on air-dried condition and that is why there was allowance for shrinkage in the cutting bill, for example $[25(+3) \mathrm{mm} \times 600(+20) \mathrm{mm}]$, the +3 and +20 are overage allowance for wood shrinkage as a result of moisture loss.

It is important that the width (on the tangential plane) of the dimensions reduces in size to take care of defect on that plane. These are referred to as recovery sizes to reduce residues in the cutting bill. What the cutting order bill earlier stated simply means is that $28 \mathrm{~mm}$ is cut for a $25 \mathrm{~mm}$ with the $+3 \mathrm{~mm}$ being the allowance for shrinkage while $600 \mathrm{~mm}$ is cut as $620 \mathrm{~mm}$, and so on. This estimated tolerance range is the standard for tropical hardwood species in timber trade when green wood are not kiln dried. These strips were then sent piece by piece to a defect marking station where a worker marks the defects on an incoming strip with a crayon by drawing lines perpendicular to the edge. These lines identify the defect from the clear sections. The strips from the marker were cross-cut in a conventional manner to specified lengths removing the defects using a cross-cut sawing machine equipped with a back-gauge. These and other defects constitute part of the wood residues that were generated.

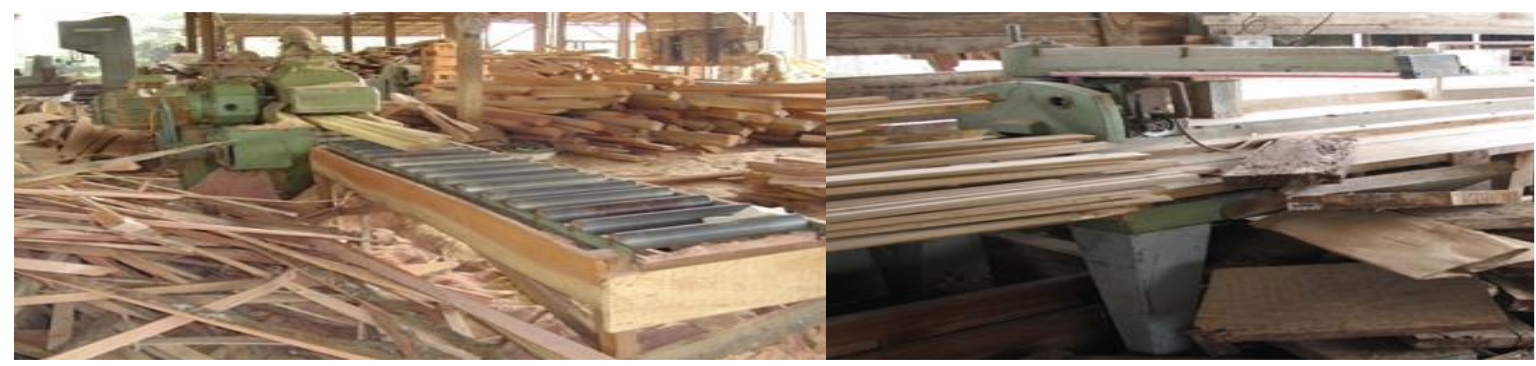

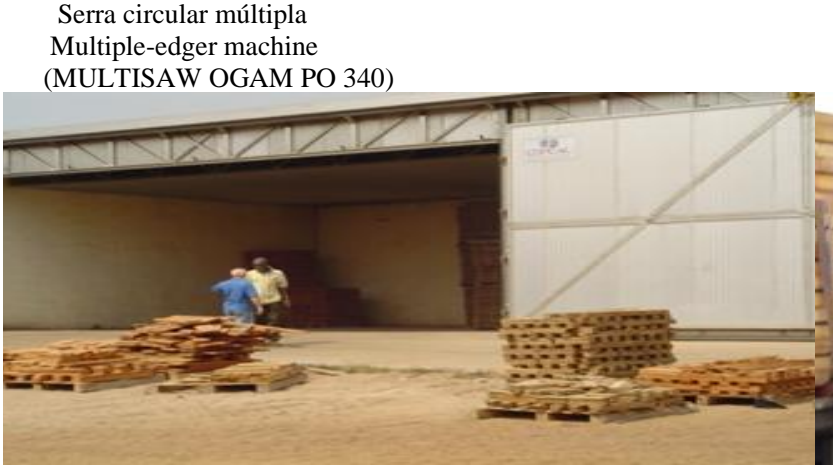

Empilhamento de peças de mobiliário Stacking of furniture parts
Serra destopedeira

Cross-cut sawing machine

(WADKIN BRA radial arm)

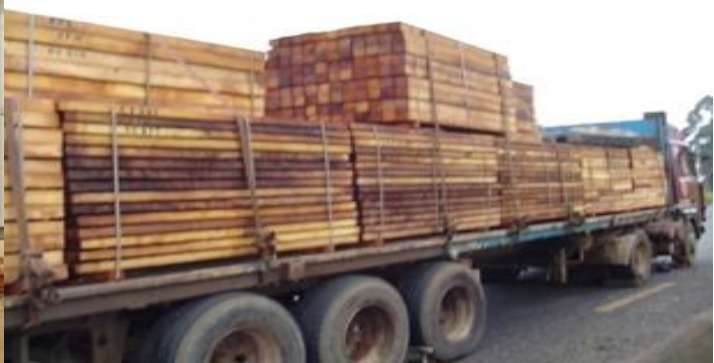

Produtos prontos para exportação

Products ready for export

Figure 1. Pictures showing multiple-edger machine, cross-cut sawing machine, the stacking of furniture parts and wood products ready for export

Figura 1: Fotos que mostram máquina de corte transversal, máquina de corte transversal, empilhamento de peças de móveis e produtos de madeira prontos para exportação

\section{Determination of Technical and Economical Residues:}

Residues, as being used here, refer to the wood, in various shapes, that does not form part of the finished product. Two types of residues were determined in this study, namely: technical and economical residues. The volume of technical residues generated was calculated by subtracting the recovered gross wood volume from the actual volume of sawnwood input while the economical residues was the difference between the recovered gross wood volume and recovered net wood volume. Gross wood recovery is also the green/wet volume recovered after wood processing without kiln drying. Sales of hardwood lumber not kiln dried usually contain additional footage for shrinkage. The net recovery is therefore, the actual wood volume the buyer pays for when the wood is not kiln dried.

FLORESTA, Curitiba, PR, v. 51, n. 1, p. 080-089, jan/mar 2021.

Larinde, S. L. et.al.

ISSN eletrônico 1982-4688 


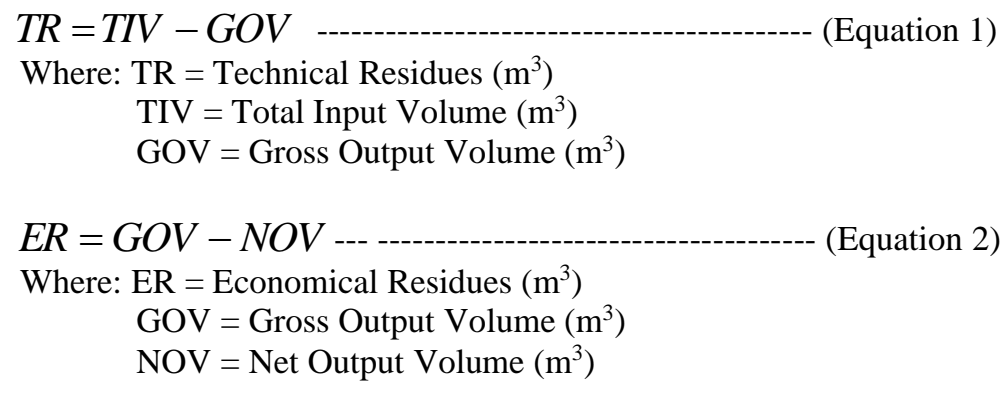

The difference between Gross Output Volume (GOV) and Net Output Volume (NOV) is the allowance for shrinkage which was not paid for by buyers but considered as economic loss and is simply termed as economical residues (ER).

\section{Statistical analysis}

Data obtained from the wood workshop were subjected to basic descriptive statistical analysis such as mean and standard error of mean. Analysis of variance (ANOVA) was also employed in analysing the data for statistical significant variation $(\mathrm{P} \leq 0.05)$. In addition, Fishers' Least Significant Difference (LSD) was applied for the separation of significantly different means $(\mathrm{P} \leq 0.05)$. Predictive equations, based on regression analysis, were developed with technical and economical residues as dependent variables for sawnwood from the three species of tree.

\section{RESULTS}

The mean values for total input volume (TIV) for sawnwood converted to the different furniture parts were $23.11 \pm 2.98 \mathrm{~m}^{3}, 24.29 \pm 1.33 \mathrm{~m}^{3}$ and $24.63 \pm 0.55 \mathrm{~m}^{3}$ for $A$. africana, M. excelsa and $T$. grandis respectively. Similarly, mean values of $12.01 \pm 1.78 \mathrm{~m}^{3}, 14.08 \pm 0.68 \mathrm{~m}^{3}$ and $16.44 \pm 0.38 \mathrm{~m}^{3}$ were obtained for gross output volume (GOV) while they were $9.52 \pm 1.42 \mathrm{~m}^{3}, 11.75 \pm 0.58^{3}$ and $14.44 \pm 0.38 \mathrm{~m}^{3}$ for net output volume (NOV) for A. africana, M. excelsa and T. grandis respectively (Table 1). However, in the case of economical residues (ER), economical residues as percentage of GOV (ERPGOV) and total volume of residues (TVR), the values obtained were: (ER = $2.49 \pm 0.40 \mathrm{~m}^{3}, 2.33 \pm 0.24 \mathrm{~m}^{3}$ and $2.00 \pm 0.10 \mathrm{~m}^{3} ;$ ERPGOV $=20.73 \pm 2.59 \%, 16.53 \pm 1.61 \%$ and $12.23 \pm 0.64 \%$; TVR $=$ $13.59 \pm 1.83 \mathrm{~m}^{3}, 12.54 \pm 0.90 \mathrm{~m}^{3}$ and $10.19 \pm 0.25 \mathrm{~m}^{3}$ ) all for A. africana, M. excelsa and T. grandis respectively (Table $1)$.

Furthermore, the mean values obtained for percentage gross recovered volume (PGRV) of wood from TIV, percentage net recovered volume (PNRV) of wood from TIV and total percentage volume of residues (TPVR) were: $(\mathrm{PGRV}=50.27 \pm 2.42 \%, 58.13 \pm 0.90 \%$ and $67.22 \pm 0.34 \% ; \mathrm{PNRV}=41.21 \pm 2.32 \%, 48.43 \pm 1.18 \%$ and $58.58 \pm 0.62 \%$; TPVR $=58.79 \pm 2.32 \%, 51.57 \pm 1.18 \%$ and $41.42 \pm 0.62 \%$ ) all for A. africana, M. excelsa and T. grandis respectively (Table 1). In addition, the ANOVA results shows that there was no significant variation in the data obtained for TIV, ER and TVR among the sawnwood from the three different tree species, while significant variation was observed to occur for data on GOV, NOV, ERPGOV, PGRV, PNRV and TPVR among the different sawnwood sourced from the three types of tree species (Table 1).

The predictive equations, obtained from regression analysis, are presented as Equations 3-8. These equations have either TR or ER as dependent variable while GOV, NOV, PGRV and PNRV served as the independent variables. The equations were developed for sawnwood from the three different tree species. Table 2-7 also have the coefficient and standard error of each predictor (dependent and independent) including the coefficient of determination $\left(\mathrm{R}^{2}\right)$, adjusted coefficient of determination (adjusted $\mathrm{R}^{2}$ ) and T-values. When the equations for estimating TR for the three species of sawnwood were compared, it was observed that Equation 5 had the highest $\mathrm{R}^{2}$ while Equation 3 had the lowest. Similarly, when the equations for estimating ER for the three species of sawnwood were compared, it was observed that Equation 8 had the highest $\mathrm{R}^{2}$ value while Equation 6 had the lowest.

Table 1. Mean values \pm their standard errors for total inputs, outputs, residues and percentage recovered volumes for the three species of wood

Tabela 1. Valores médios \pm seus erros padrão para insumos totais, produtos, resíduos / resíduos e porcentagem de volumes recuperados para as três espécies de madeira 


\begin{tabular}{|c|c|c|c|c|c|c|c|c|c|}
\hline Species & $\begin{array}{l}T I V \\
\left(m^{3}\right)\end{array}$ & $\begin{array}{c}G O V \\
\left(m^{3}\right)\end{array}$ & $\begin{array}{c}\text { NOV } \\
\left(m^{3}\right)\end{array}$ & $\begin{array}{c}E R \\
\left(m^{3}\right) \\
\end{array}$ & $\begin{array}{c}\text { ERPGOV } \\
(\%)\end{array}$ & $\begin{array}{l}T V R \\
\left(m^{3}\right) \\
\end{array}$ & $\begin{array}{c}P G R V \\
(\%)\end{array}$ & $\begin{array}{c}\text { PNRV } \\
(\%)\end{array}$ & $\begin{array}{c}\text { TPVR } \\
(\%) \\
\end{array}$ \\
\hline Afzelia & $23.11 \pm$ & $12.01 \pm$ & $9.52 \pm$ & $2.49 \pm$ & 20.73 & $13.59 \pm$ & $50.27 \pm$ & $41.21 \pm$ & $58.79 \pm$ \\
\hline africana & $2.98 \mathrm{a}$ & $1.78 \mathrm{a}$ & $1.42 \mathrm{a}$ & $0.40 \mathrm{a}$ & $\pm 2.59 \mathrm{a}$ & $1.83 \mathrm{a}$ & $2.42 \mathrm{a}$ & $2.32 \mathrm{a}$ & $2.32 \mathrm{a}$ \\
\hline $\begin{array}{l}\text { Milicia } \\
\text { excelsa }\end{array}$ & $\begin{array}{c}24.29 \pm \\
1.33 \mathrm{a}\end{array}$ & $\begin{array}{l}14.08 \pm \\
0.68 \mathrm{~b}\end{array}$ & $\begin{array}{l}11.75 \pm \\
0.58 \mathrm{~b}\end{array}$ & $\begin{array}{l}2.33 \pm \\
0.24 \mathrm{a}\end{array}$ & $\begin{array}{c}16.53 \\
\pm 1.61 \mathrm{~b}\end{array}$ & $\begin{array}{c}12.54 \pm \\
0.90 \mathrm{a}\end{array}$ & $\begin{array}{c}58.13 \pm \\
0.90 \mathrm{~b}\end{array}$ & $\begin{array}{c}48.43 \pm \\
1.18 \mathrm{~b}\end{array}$ & $\begin{array}{c}51.57 \pm \\
1.18 \mathrm{~b}\end{array}$ \\
\hline $\begin{array}{l}\text { Tectona } \\
\text { grandis }\end{array}$ & $\begin{array}{r}24.63 \pm \\
0.55 \mathrm{a}\end{array}$ & $\begin{array}{r}16.44 \pm \\
0.38 \mathrm{c}\end{array}$ & $\begin{array}{c}14.44 \pm \\
0.38 \mathrm{c}\end{array}$ & $\begin{array}{l}2.00 \pm \\
0.10 \mathrm{a}\end{array}$ & $\begin{array}{c}12.23 \\
\pm 0.64 \mathrm{c}\end{array}$ & $\begin{array}{c}10.19 \pm \\
0.25 \mathrm{a}\end{array}$ & $\begin{array}{c}67.22 \pm \\
0.34 \mathrm{c}\end{array}$ & $\begin{array}{c}58.58 \pm \\
0.62 \mathrm{~b}\end{array}$ & $\begin{array}{c}41.42 \pm \\
0.62 \mathrm{~b}\end{array}$ \\
\hline
\end{tabular}

Each value is the mean for data obtained from twelve experimental replications

Means with the same superscripts in the same column are not significantly different $(\mathrm{P} \leq 0.05)$

TIV = Total Input Volume

GOV = Gross Output Volume

NOV $=$ Net Output Volume

$\mathrm{ER}=$ Economical Residues

ERPGOV = Economical Residues as percentage of GOV

TVR $=$ Total Volume of Residues

PGRV = Percentage Gross Recovered Volume of wood from TIV

PNRV = Percentage Net Recovered Volume of wood from TIV

TPVR $=$ Total Percentage Volume of Residues

$$
T R_{A f z a f r}=14.19+4.15 G O V_{A f z a f r}-4.33 N O V_{A f z a f r}-0.13 P G R V_{A f z a f r}-0.14 P N R V_{A f z}
$$

Table 2. Results of linear regression analysis for Equation 3

Tabela 2. Resultados da análise de regressão linear para a Equação 3

\begin{tabular}{|c|c|c|c|c|c|}
\hline Predictor & Coefficient & Standard Error & $\begin{array}{c}R^{2} \\
(\%)\end{array}$ & $\begin{array}{c}\text { Adjusted } \\
R^{2}(\%)\end{array}$ & $T$ \\
\hline Constant Afzafr & 14.18981 & 7.198593 & & & 1.97 \\
\hline $\mathrm{GOV}_{\text {Afzafr }}$ & 4.153976 & 2.494744 & & & 1.67 \\
\hline $\mathrm{NOV}_{\text {Afzafr }}$ & -4.33402 & 3.150423 & 78.65 & 66.44 & -1.38 \\
\hline PGRV $_{\text {Afzafr }}$ & -0.1281297 & 0.5142644 & & & -0.25 \\
\hline PNRV $_{\text {Afzafr }}$ & -0.1364241 & 7.198593 & & & -0.27 \\
\hline
\end{tabular}

$$
T R_{\text {Milexc }}=24.55+0.69 G O V_{\text {Milexc }}-0.49 N O V_{\text {Milexc }}-0.40 P G R V_{\text {Milexc }}-0.03 P N R V_{\text {Milexc }}^{---------~(E q u a t i o n ~ 4) ~}
$$

Table 3. Results of linear regression analysis for Equation 4

\begin{tabular}{|c|c|c|c|c|c|}
\hline Predictor & Coefficient & Standard Error & $\begin{array}{c}R^{2} \\
(\%)\end{array}$ & $\begin{array}{c}\text { Adjusted } \\
R^{2}(\%)\end{array}$ & $T$ \\
\hline Constant Milexc & 24.54763 & 2.70516 & & & 9.07 \\
\hline $\mathrm{GOV}_{\text {Milexc }}$ & 0.693843 & 0.1142918 & & & 6.07 \\
\hline $\mathrm{NOV}_{\text {Milexc }}$ & -0.485167 & 0.1303933 & 99.01 & 98.44 & 0.37 \\
\hline PGRV $_{\text {Milexc }}$ & -0.3989103 & 0.312466 & & & -12.77 \\
\hline PNRV $_{\text {Milexc }}$ & -0.0261488 & 0.237583 & & & -1.10 \\
\hline
\end{tabular}

Tabela 3. Resultados da análise de regressão linear para a Equação 4

$$
T R_{\text {Tecgra }}=26.75-0.95 G O V_{\text {Tecgra }}+1.63 N O V_{\text {Tecgra }}-0.38 P G R V_{\text {Tecgra }}-0.41 P N R V_{\text {Tecgra }}^{-----------~(E q u a t i o n ~ 5) ~}
$$

Table 4. Results of linear regression analysis for Equation 5

Tabela 4. Resultados da análise de regressão linear para a Equação 5 


\begin{tabular}{|c|c|c|c|c|c|}
\hline Predictor & Coefficient & Standard Error & $\begin{array}{c}R^{2} \\
(\%)\end{array}$ & $\begin{array}{c}\text { Adjusted } \\
R^{2}(\%)\end{array}$ & $T$ \\
\hline Constant ${ }_{\text {Tecgra }}$ & 26.75203 & 1.05841 & & & 25.28 \\
\hline $\mathrm{GOV}_{\text {Tecgra }}$ & -0.9485979 & 0.069175 & & & -13.71 \\
\hline $\mathrm{NOV}_{\text {Tecgra }}$ & 1.633531 & 0.0764343 & 99.71 & 99.55 & 21.37 \\
\hline PGRV $_{\text {Tecgra }}$ & -0.381555 & 0.0195958 & & & -1.95 \\
\hline PNRV $_{\text {Tecgra }}$ & -0.4092362 & 0.0129158 & & & -31.68 \\
\hline
\end{tabular}

$$
E R_{A f z a f r}=3.66+0.48 G O V_{A f z a f r}+0.22 N O V A_{f z a f r}-0.15 P G R V_{A f z a f r}+0.09 P N R V_{A f z a f r}{ }^{--------------~(E q u a t i o n ~ 6) ~}
$$

Table 5. Results of linear regression analysis for Equation 6

Tabela 5. Resultados da análise de regressão linear para a Equação 6

\begin{tabular}{cccccc}
\hline Predictor & Coefficient & Standard Error & $\begin{array}{c}\boldsymbol{R}^{\mathbf{2}} \\
(\boldsymbol{\%})\end{array}$ & $\begin{array}{c}\text { Adjusted } \\
\boldsymbol{R}^{\mathbf{2}}(\boldsymbol{\%})\end{array}$ & $\boldsymbol{T}$ \\
\hline Constant $_{\text {Afzafr }}$ & 3.663374 & 1.815306 & & & 2.02 \\
GOV $_{\text {Afzafr }}$ & 0.0476355 & 0.6291125 & & & 0.08 \\
NOV $_{\text {Afzafr }}$ & 0.2155041 & 0.7944585 & 81.42 & 70.81 & 0.27 \\
PGRV $_{\text {Afzafr }}$ & -0.1480739 & 0.1296847 & & & -1.14 \\
PNRV $_{\text {Afzafr }}$ & 0.0934565 & 0.1278921 & & & 0.73 \\
\hline
\end{tabular}

$E R_{\text {Milexc }}=-0.00003+0.99 G O V_{\text {Milexc }}-0.99 N O V_{\text {Milexc }}-0.00004 P G R V_{\text {Milexc }}+0.00003 P N R V_{\text {Mile } x}$

7)

Table 6. Results of linear regression analysis for Equation 7

Tabela 6. Resultados da análise de regressão linear para a Equação 7

\begin{tabular}{|c|c|c|c|c|c|}
\hline Predictor & Coefficient & Standard Error & $\begin{array}{l}R^{2} \\
(\%)\end{array}$ & $\begin{array}{c}\text { Adjusted } \\
R^{2}(\%)\end{array}$ & $T$ \\
\hline Constant Milexc & -0.0000322 & 0.0021862 & & & -0.01 \\
\hline $\mathrm{GOV}_{\text {Milexc }}$ & 0.9998871 & 0.0000924 & & & $1.1 \mathrm{e}+04$ \\
\hline $\mathrm{NOV}_{\text {Milexc }}$ & -0.9998098 & 0.0001054 & 99.94 & 99.91 & -9487.73 \\
\hline PGRV $_{\text {Milexc }}$ & -0.0000371 & 0.0000253 & & & -1.47 \\
\hline PNRV $_{\text {Milexc }}$ & 0.0000258 & 0.0000192 & & & 1.34 \\
\hline
\end{tabular}

$$
E R_{\text {Tecgra }}=-0.0001+0.99 G O V_{\text {Tecgra }}-0.99 N O V_{\text {Tecgra }}+0.00003 P G R V_{\text {Tecgra }}-0.0000002 P N R V_{\text {Tecgra }}
$$

(Equation 8)

Table 7. Results of linear regression analysis for Equation 8

\begin{tabular}{|c|c|c|c|c|c|}
\hline Predictor & Coefficient & Standard Error & $\begin{array}{c}R^{2} \\
(\%) \\
\end{array}$ & $\begin{array}{c}\text { Adjusted } \\
R^{2}(\%)\end{array}$ & $T$ \\
\hline Constant Tecgra & -0.0001398 & 0.005825 & & & -0.02 \\
\hline $\mathrm{GOV}_{\text {Tecgra }}$ & 0.9996233 & 0.0003807 & & & 2625.72 \\
\hline $\mathrm{NOV}_{\text {Tecgra }}$ & -0.9997032 & 0.0004207 & 99.96 & 99.92 & -2376.53 \\
\hline PGRV $_{\text {Tecgra }}$ & 0.0000311 & 0.0001078 & & & 0.29 \\
\hline PNRV $_{\text {Tecgra }}$ & $-2.16 \mathrm{e}-06$ & 0.0000711 & & & -0.03 \\
\hline \multicolumn{6}{|l|}{$\begin{array}{l}\mathrm{P} \leq 0.05 \\
\text { Note: For Table } 2-7\end{array}$} \\
\hline $\begin{array}{lll}\mathrm{TR}_{\text {Afzafr }} & =\text { Tec } \\
\mathrm{GOV}_{\text {Afzafr }} & = & \text { Gro } \\
\text { NOV }_{\text {Afzafr }} & = & \text { Net } \\
\text { PGRV }_{\text {Afzafr }} & = & \text { Perc } \\
\text { PNRV }_{\text {Afzafr }} & \text { Percenta }\end{array}$ & $\begin{array}{l}\text { idues for wood } \mathrm{f} \\
\text { Volume for woo } \\
\text { olume for wood } \mathrm{f} \\
\text { oss Recovered V } \\
\text { covered Volume }\end{array}$ & $\begin{array}{l}\text { m Afzelia africana } \\
\text { rom Afzelia africana } \\
\text { m Afzelia africana } \\
\text { ume for wood from Af } \\
\text { r wood from Afzelia a }\end{array}$ & a africana & & \\
\hline
\end{tabular}

Tabela 7. Resultados da análise de regressão linear para a Equação 8

FLORESTA, Curitiba, PR, v. 51, n. 1, p. 080-089, jan/mar 2021.

Larinde, S. L. et.al.

ISSN eletrônico 1982-4688 


\section{DISCUSSION}

When sawnwood is converted into furniture parts, as done in this study, residues - categorised here into technical and economical - are generated in various ways and quantities. Technical residues includes sawdust from wood conversions by machines (multiple rip-saw, cross-cutting and the ones for bringing wood to desired planes) edging and trimmings from length and width reductions, removal of defective parts from pieces of lumber, among others. Technical residues were as a result of grading and quality control to get a very sound lumber free of defects. High quality grade of lumber results in minimal waste in production because there are little defects. On the other hand, an economical residue in the production of furniture parts, for instance, can be described as the volume of wood earmarked to meet the overage allowance when sawnwood and/or lumber to be converted is not seasoned (kiln-dried) to moisture content low enough to the level where significant shrinkage is prevented or unexpected. This overage allowance, as used here, is the total volume of wood needed to satisfy the cutting bill, including parts of all the fixed lengths, widths and thicknesses (nominal sizes minus actual sizes).

Through the application of Equation 1, it was observed that more TR was generated from A. africana followed by M. excelsa and T. grandis in that order, during the conversion of sawnwood to furniture parts in this study. The reason(s) for this outcome is/are beyond the scope of this reported study. Irrespective of this, published data in literature showed that $A$. africana's density ranged between 720 and $850 \mathrm{~kg} / \mathrm{m}^{3}$ while those for $M$. excelsa and $T$. grandis ranged from 550 to $750 \mathrm{~kg} / \mathrm{m}^{3}$ and $(480-) 610-730(-850) \mathrm{kg} / \mathrm{m}^{3}$ respectively at $12 \%$ moisture content (LOUPPE 2005, OFORI 2007, GÉRARD; LOUPPE 2011). This observation whereby it appeared that more TR were generated by sawnwood from the supposedly higher density tree species in comparison with those with lower density values is recommended for scientific investigation.

Furthermore, as earlier stated, the mean values for the difference between GOV and NOV (i.e. ER) was $2.00 \pm 0.10 \mathrm{~m}^{3}, 2.33 \pm 0.24 \mathrm{~m}^{3}$ and $2.49 \pm 0.40 \mathrm{~m}^{3}$ for $T$. grandis, M. excelsa and A. africana respectively (Table 1). Apart from the impacts of these ER values, the other economic implication of overage allowance is that the buyer of these three species in this form of processed wood will pay for volume of wood that is compensated for with between $3 \mathrm{~m}^{3}$ and $5 \mathrm{~m}^{3}$ of wood by the seller. For example, when loading a 20ft. container that can contain between $21 \mathrm{~m}^{3}$ and $23 \mathrm{~m}^{3}$ with processed wood for export, the buyer pays for about $18 \mathrm{~m}^{3}$ with the seller loosing between $3 \mathrm{~m}^{3}$ and $5 \mathrm{~m}^{3}$ volume of wood because of the overage allowance for shrinkage. Thus, by multiplying the lost wood volume by current price, i.e. minimum of approximately US $\$ 580.00 / \mathrm{m}^{3}$ (free on board), the economic loss, by the seller, for every $20 \mathrm{ft}$. container of the processed wood in the form of furniture parts from sawnwood obtained from the three species of tree could be estimated and appreciated.

Economical residues can be eliminated in production when lumber is well seasoned through kiln drying and this will in turn increase the volume of recovered wood per processed sawnwood. Any decrease in residues will save money and increase the profitability of the enterprise. Part of the TR generated may be used by smaller furniture makers as raw material while the rest may be utilised for energy generation in the form of biomass fuel. It is also important that uses are found for these residues through their conversion into higher value products such as interior parts of furniture. This is a part of a furniture frame that is hidden from view. Its primary function is strength, it can contain any sound defects that does not materially weaken the strength of the piece and does not occur in the outer part where machining for joining is necessary.

Table 1 also shows that the ratio of the difference between TIV and GOV to TIV (in percentage) gave mean values - for the different sawnwood from the three tree species - that fell within the range documented for cubic lumber recovery for some wood from tropical tree species by Badejo and Giwa (1985), Rappold et al. (2007), Okunomo et al. (2007), Egbewole et al. (2011) and Erakhrumen and Idele (2016). The likely implication of this outcome is that recoverable wood volume from the sawnwood and machined wood appeared to be within the range observed by these earlier studies. The reason for this - if the types of machine used for converting sawnwood to furniture parts in this workshop are put into consideration - may not be unconnected with the country's current level of human capacity development and low technological advancement in the sawmilling industry (EGBEWOLE et al. 2011, ERAKHRUMEN; IDELE, 2016). This, as earlier stated, is a justification for this study aimed at highlighting the necessity for surmounting this challenge by adopting and investing on improved human capacity and technology/related machineries like those that have helped in other climes with positive impacts on outputs as documented in study outcomes such as Keegan et al. (2010) and Blatner et al. (2012).

The reason(s) for the results obtained for ANOVA indicated in Table 1 may not be easily ascertained in this research since all the sawnwood and machined wood from which data was collected were from different tree species with different intrinsic and extrinsic influences on them and their properties. However, the dimensions were approximately the same for sawnwood from the three different tree species before they were converted to furniture parts thereby making the TIV calculated for them to be similar and this is most likely the explanation for the non-significance in data variation concerning TIV among the species. Also, the non-significance in data variation for ER among the three species of sawnwood after conversion to furniture parts is likely to be as a result

FLORESTA, Curitiba, PR, v. 51, n. 1, p. 080-089, jan/mar 2021.

Larinde, S. L. et.al.

ISSN eletrônico 1982-4688

DOI: 10.5380/rf.v51 i1. 67331 
of the overage allowance being the same in all three of them even as issues that has to do with moisture content was important. Similarly, the observation made concerning the non-significance of variation in data in TVR might also have to do with the experience with ER and influence of TR.

Furthermore, the results of statistical analysis, particularly coefficient of determination $\left(\mathrm{R}^{2}\right)$ showed that the regression equations developed for M. excelsa and T. grandis had better predictive power than those developed for $A$. africana. This does not, in any way, mean that the regression equations, developed in this context for $A$. africana, are not appropriate for the proposed predictive purposes. In the same way, ANOVA for the developed equations also showed that their predictive powers were significant with $95 \%$ confidence, meaning that the developed equations may be applied for estimations of TR and ER using the independent variables earlier defined. The implication of the foregoing is that the equations may be employed for predictions when the values of TR and ER are not readily available; however, appropriate precautionary measures that will assist in preventing a condition known as auto-correlation among the independent variables should be put in place. These precautionary measures are necessary as auto-correlation, when present, has been discovered to be a contributory factor to cases of reduction in predictive equations' efficiency and reliability.

\section{CONCLUSION}

The conclusions reached, based on the outcomes of this study, are:

- Appreciable volume of wood, either in the form of technical or economical residues, was lost during secondary conversion, of wood, to furniture parts, in this wood processing outfit.

- High technical and economical residues were incurred partly as a result of inadequate and/or lack of appropriate up-to-date technology and equipments in this wood processing outfit.

- These types of losses were also contributed to by allowance given for shrinkage resulting from moisture loss from non kiln-dried wood being sold or supplied, by the wood processing outfit, particularly for export.

- This and other similar wood processing outfits in Nigeria should invest on improved wood processing methods and facilities that will facilitate reduction in these and other types of residues to tolerable minimum.

- It is expected that significant reduction in the types of residues identified in this study will be accompanied by increment in economic advantage and support for sustainability of wood sourcing from the country's forests.

\section{REFERENCES}

AKANDE, J.A.; LARINDE, S.L.; NTABE, E.; ADU-ANNING, C.; AGBEJA, B.O. Towards forest industrial reform in Ghana, Nigeria and Cameroon. Discovery and Innovation Journal, Nairobi, v. 19, n. 3, p. 181-189, 2007.

BADEJO, S.O.O.; GIWA, S.A. Volume assessment and economic importance of wood waste utilization in Nigeria. Forestry Research Institute of Nigeria (FRIN) Technical Report No. 50, 1985.

BLATNER, K.A.; KEEGAN III, C.E.; DANIELS, J.M.; MORGAN, T.A. Trends in lumber processing in the western United States. Part III: Residue recovered versus lumber produced. Forest Products Journal, LaGrange, GA., v. 62, n. 6, p. 429-433, 2012.

EGBEWOLE, Z.T.; OGUNSANWO, O.Y.; OMOLE, A.O. Technical efficiency of lumber recovery from high forest tree species in selected sawmills of southwestern Nigeria. Nigerian Journal of Agriculture, Food and Environment, Uyo, v. 7, n. 1, p. 34-41, 2011.

ERAKHRUMEN, A.A.; IDELE, N.R. Recovery efficiency of lumber/sawnwood from prioritised wood species in selected sawmills within Egor Local Government Area, Edo State, Nigeria. Ibadan Journal of Agricultural Research, Ibadan, v. 12, n. 1, p. 21-30, 2016.

ERAKHRUMEN, A.A.; ONYMALI, G. Log volume estimations for some prioritised wood species converted in sawmills within Egor Local Government Area, Edo State, Nigeria. Journal of Agriculture, Forestry and Fisheries, Benin, v. 15, n. 1, p. 86-91, 2016.

FAO. Annual book of trade statistics. Food and Agriculture Organization (FAO) of the United Nations, Rome, 2000.

FAO. Forest products definitions: General terms. Food and Agriculture Organization (FAO) of the United Nations, Rome, 2016. Available at: www.fao.org/forestry/36058-02d9152c9571f5e09b9b54a76d37d47f3.pdf

FLORESTA, Curitiba, PR, v. 51, n. 1, p. 080-089, jan/mar 2021.

Larinde, S. L. et.al.

ISSN eletrônico 1982-4688

DOI: 10.5380/rf.v51 i1. 67331 
FERN, K. Useful tropical plants database 2014 by Ken Fern, web interface by Ajna Fern with help from Richard Morris: Afzelia africana Sm. ex Aers. Available http://tropical.theferns.info/viewtropical.php?id=Afzelia+africana Updated on 13-06-2019.

GÉRARD, J.; LOUPPE, D. Afzelia africana Sm. ex Pers. In: LEMMENS, R.H.M.J.; LOUPPE, D.; OTENGAMOAKO, A.A. (Editors) PROTA (Plant resources of tropical Africa / Ressources végétales de l'Afrique tropicale), Wageningen, Netherlands, 2011. Available at: https://uses.plantnetproject.org/en/Afzelia_africana_(PROTA) Accessed 7 October 2019.

ITTO. Annual review and assessment of the world timber situation 2000. International Tropical Timber Organization (ITTO), Yokohama, 2000, 195p.

IUCN Red List of threatened species. Available at: https://www.iucnredlist.org/

KEEGAN III, C.E.; MORGAN, T.A.; BLATNER, K.A.; DANIELS, J.M. Trends in lumber processing in the western United States. Part II: Overrun and lumber recovery factors. Forest Products Journal, LaGrange, GA., v. 60, n. 2, p. 140-143, 2010.

LARINDE, S.L.; AKANDE, J.A.; BADEJO, S.O. Lumber recovery from selected plantation-grown hardwood species in Onigambari forest reserve, south west, Nigeria. Bowen Journal of Agriculture, Iwo, v. 3, n. 1, p. 99$105,2006$.

LARINDE, S.L.; ERAKHRUMEN, A.A.; OJOH, D. Utilisation of wood residues from a cluster of sawmills at Illabuchi by inhabitants of some adjoining communities in Port Harcourt, Nigeria. Journal of Research in Forestry, Wildlife and Environment, Makurdi, v. 10, n. 4, p. 118-125, 2018.

LARINDE, S.L.; POPOOLA, L. Socio-economic assessment of secondary wood processing in Nigerian sawmills. Journal of Agriculture, Forestry and the Social Sciences, Obubra, v. 6, n. 2, p. 22-28, 2008.

LOUPPE, D. Tectona grandis L.f. In: LOUPPE, D.; OTENG-AMOAKO, A.A.; BRINK, M. (Editors) PROTA (Plant resources of tropical Africa / Ressources végétales de l'Afrique tropicale), Wageningen, Netherlands, 2005. Accessed 7 October, 2019.

NOACK, D. Making Better use of tropical timber resources. Tropical Forest Update, Yokohama, v. 5, n. 2, p. 12-14, 1995.

OFORI, D.A. Milicia excelsa (Welw.) C.C. Berg. In: LOUPPE, D.; OTENG-AMOAKO, A.A.; BRINK, M. (Editors) PROTA (Plant resources of tropical Africa / Ressources végétales de l'Afrique tropicale), Wageningen, Netherlands, 2007. Accessed 7 October, 2019.

OKUNOMO, K.; ACHOJA, F.O.; AGBOGIDI, O.M.; ONOSODE, A.T. Economics of wood conversion efficiency and plank yield estimation among different wood species. Agricultural Journal, Dubai, v. 2, n. 6, p. 726-730, 2007.

RAPPOLD, P.M.; BOND, B.H.; WIEDENBECK, J.K.; ESE-ETAME, R. Impact of elliptical shaped red oak logs on lumber grade and volume recovery. Forest Products Journal, LaGrange, GA., v. 57, n. 6, p. 70-73, 2007.

FLORESTA, Curitiba, PR, v. 51, n. 1, p. 080-089, jan/mar 2021.

Larinde, S. L. et.al.

ISSN eletrônico 1982-4688

DOI: $10.5380 /$ rf.v51 i1. 67331 